Компаративні досліАження слов'янських мов і мітератур. 2019. Випуск 35

літературі виникає не зі слів, а 3 поєднання їх, зі стосунків між персонажами твору і навіть 3 домислу читача, який $\epsilon$ обов'язковим учасником літературного творення. Чому, наприклад, захоплює образ «Таємниця твого обличчя»? Бо читач прочитує в ньому не саме лиш «обличчя». Там є символ краси всієї кращої половини людства. Таке ж узагальнення містить у собі символ людського єднання («Слово...»), прагнення свободи без кайданів («De libertate», «Заповіт»), чарівність «Зів'ялого листя», «Лісової пісні», «Сонячних кларнетів», «Зачарованої Десни» й «Троянд і винограду», протест проти наруги над людською цивілізацією («Жовтий князь», «Сад гетсиманський») і над соборами людських душ («Собор»). Критика такі твори обов’язково помічала й помічатиме, а за ваговитістю в літературному процесі вона буде завжди такою ж, як і сама художня література. Бо вона - похідна від неї і тому горітиме завжди тим самим вогнем, що й вона. Недавня книжка літературної критики Тараса Салиги так і називається: «Вогонь, що не згаса» (2017).

\title{
REFERENCES:
}

1. Literaturnaya encyklopedia (1929), T.2, Moskva.

Свербілова Т. д.філол.н., Інститут літератури імені Т.Г.Шевченка НАН України (Україна) Sverbilova T. Doctor of Philology, Taras Shevchenko Institute of Literature, National Academy of Sciences of Ukraine (Ukraine)

\author{
ДИСКУРС ТРАНСКУЛЬТУРАЦЇ ТА КУЛЬТУРНОЇ \\ ГІБРИДНОСТІ ЯК ПРЕДМЕТ ЛІТЕРАТУРНОЇ \\ КОМПАРАТИВІСТИКИ
}

\section{DISCOURSE OF TRANSCULTURATION AND CULTURAL HYBRIDITY AS COMPARATIVE LITERATURE SUBJECT}


3 погляду літературної компративістики розглядаються теорії гібридної культури i транскультуралізму. В сучасному світі відбувається трансформація мультикультуралізму і глобалізму у бік транскультуращї, щзо є невідворотним наслідком ускладнених процессів культурної взаимодї в усьому світі. Транскультурація до певної міри $\epsilon$ альтернативою мультикультуралізму як продукту глобалізму і має відмінну від мультикультуралізму риторику Іншого.

Концепт транскультурації Ф. Ортіса як альтернативи асиметричній концепиії акультурації в зоні культурних контактів надав можливості опису складних процесів культурної взаємодії і в епоху глобалізаџії. Транскультурацію засновано на культурному полілозі, в якому не повинно відбуватися повного синтезу, де культури зберігають певну непрозорість. Поняття транскультурності може бути використаним як основа для сучасного компаративного аналізу літератури.

Водночас, не розв'язані ключові питання взаємодї культур у пострадянському дискурсі. Тому дослідження методологій пострадянських студій має важливе не тільки теоретичне, але й загальнокультурне значення. Карибська філософія, що будується як значний прошарок сучасної компаративістики у галузі взаємодії культур - безпосередньо стосується проблем вибору шляхів подальшого постколоніального розвитку пострадянських культур. Транскультурація висуває принцип гібридності замість архаӥчного принцииу чистоти національної культури, декларує зміну ставлення до національних мов, культурних традицій $i$ самого поняття нації-держави, щуо поступаються місцем процесам транснаціоналізації $i$ поліглосії, пов'язаним з принципом мережевого космополітизму. Це нові стосунки між мовами і культурами. У кінцевому рахунку изе нові імагологічні взаємодії між Своїм та Іншим, це пошук нової єдності різних Інших.

Ключові слова: методологї літературної компаративістики, постколоніальні студіі, транскультуралізм, гібридність, мультикультуралізм, глобалізм, пострадянські студї, культурна ідентичність.

Theories of hybrid culture and transculturalism are analyzed from the point of view of comparative literature. In the modern world the transformation of multiculturalism and globalism towards transculture is an inevitable consequence of the complicated processes of cultural interaction in all countries of the world. Transculturalism is an alternative to multiculturalism as a product of globalism and has different rhetoric of the Other. The transcultural concept, put forward by F. Ortiz as an alternative to the asymmetric concept of acculturation in the area of cultural contacts, provided opportunities for describing the complex processes of cultural interaction in the era of globalization. Transculture is based on the cultural polyphony, in which there should 
not be a complete synthesis, where the cultures retain some opacity. The concept of transculturality can be used as a basis for a modern comparative analysis of literature. At the same time, key issues of interaction of cultures in post-Soviet discourse are not solved. Therefore, the study of methodologies of post-Soviet studies is important not only as theoretical problem, but also as a problem of general cultural significance. Therefore, the Caribbean philosophy, which is being built as a significant element of contemporary comparativism in the field of interaction between cultures, directly concerns the problems of choosing ways of further postcolonial development of postSoviet cultures. Transculturalism proposes the principle of hybridity instead of the archaic principle of the purity of national culture, declaring the change in attitude to national languages, cultural traditions and the very concept of nation-state, giving way to the processes of transnationalization and polyglossia associated with the principle of the networked cosmopolitanism. This is a new relationship between languages and cultures. Ultimately, this new andmagological interaction between the Own and the Other. It is a search for a new unity of the various Others.

Key words: comparative literature, postcolonial studies, transculturalism, hybridization, multiculturalism, globalism, post-Soviet studies, cultural identity.

Транскультурація, що прийшла на заміну мультикультуралізму з одного боку і глобалізму з іншого боку, є невідворотним наслідком ускладнених процессів культурної взаимодії в усьому світі. Хоча ця проблематика традиційно може бути віднесеною до компаративістики, але літературною компаративістикою ще вивчалася недостатньо як на матеріалі порівняльного аналізу вітчизняної літератури та літератур Європи та Америки, так і на матеріалі постколоніальних літератур Східної Європи. У цьому перший аспект актуальності цієї теми.

Транскультурація - це поняття, уведене вперше кубінським антропологом Ф. Ортісом [Ortiz 1995] у 1940 році як альтернатива загальновживаним на той час асимертичним концепціям акультурації односпрямованого перекладу у зоні культурних контактів (за визначенням британського антрополога польського походження Б. Малиновського), неповну асиміляцю, зберіганні Іншості у чужому середовищі. У подальшому це була можливість опису складних процесів культурної взаємодії в епоху глобалізації. 
Наразі термін вживається у постколоніальних студіях у категоріях імперського-колоніального. Транскультурацію засновано на динамічному різноманітті, в цьому феномені пропонується нове осмислення як старих явищ різноманіття культур і полілінгвіальності, так і актуалізованих транснаціональних мов, дискурсів і традицій, що вийшли на перший план в культурних процесах кінця XX - початку XXI ст. Транскультурацію засновано на сучасній неминучій взаємодії культур, на культурному полілозі, в якому не повинно відбуватися повного синтезу, злиття, повного культурного перекладу, де культури зустрічаються, взаємодіють, але не зливаються, зберігаючи певну непрозорість. Карибський філософ Е. Гліссан стверджував не тільки «право на на відмінність, а й право на непрозорість, що розуміється не як закритість всередині непроникної автократичної культури, але як твердження своєї особливої суті в рамках унікальності, що не знищується» [Glissant 1997].

Поняття транскультурності може бути основою для аналізу літератури в епоху глобалізації.

Категорія культурної гібридизації використовується для культур прикордонного типу, де визначається спільна ідентичність, не пов'язана 3 національною, мовною однаковістю (наприклад, Карибська ідентичність). Транскультурація не стирає відмінності між культурами, а включає їх в творчий ігровий процес (Вілсон Харріс, Жак Дерріда). Хомі Бгабга, у свою чергу, більше цікавиться феноменном антагоністичної зустрічі на кордоні культур, що артикулюється як порожнеча. Моделі транскультурації дають опис постмодерного світу як трансформації хаосу у порядок, надають можливості виходу з ситуації постмодерну. Теорія культурної гібридності Хомі Бгабги, що породжує «позадомність», у якій існує сучасний індивід, містить основи трактування культурної гібридності як транскультурного феномену. Методологічною основою для дослідження транскультурної літератури є концепція продуктивної культурної гібридності. Дослідник звертає увагу на національну ідентичність, що будується на кордонах, «3 того боку», у просторі «за межами» гомогенної культури або «у проміжку» між різними культурами. У праці «The Location of Culture» [Bhabha 1994] Хомі Бгабга стверджує, що світову літературу необхідно розглядати через призму таких загальних тем, як історична травма, рабство, геноцид, 
вигнання, втрата культурної ідентичності. При цьому «культурна відмінність» проявляється у «змішаному та розколотому гібридному тексті». Таким чином, гібридна ідентичність стає одним акторів структури художнього тексту з ногляду транскультуралізму.

Тенденція до зрощення постколоніальних i пострадянських (пост-тоталітарних) студій - вельми популярна останнім часом в країнах колишнього СРСР. Власне, перенесення інтересів 3 орієнталізму, заснованого Саїдом, де домінував погляд метрополії на колонії, - на окциденталізм, де створювався погляд колоній на метрополію, - надавав можливість опису радянських і пострадянських практик як імперської системи 3 категоріями колоніального i неоколоніального поневолення і залежності. Ще Е. Саїд у монографії «Culture and Imperialism» пропонує «новий порівняльний контрапунктний підхід» [Said 1994: 51], вважаючи це головною інноваційною парадигмою гуманітаристики. Е. Саїд наполягає на перегляді уявлень про те, що література існує у національних рамках. А, наприклад, Л. Хатчен визначає цей новий підхід до дослідження культури епохи глобалізації як «компаративний транснаціональний фокус» [Hutcheon 2002: 26].

Теоретичні проблеми сучасної транскультураціі як епістемологічної моделі процесів глобалізації розглядаються Маденою Тлостановою, котра спирається на давні дослідження кубинця Ф. Ортіса i використовує термін Фуко «епістема» по відношенню до теорії транскультураціі. Як вторинної культурної моделі «транскультура» розробляється починаючи 3 1980-х років Михайлом Епштейном. Перенесення ж загальних положень теорії транскультураціі і пов'язаної 3 нею гібридизації на ситуацію постколоніальної дійсності східнослов'янського регіону - наразі не проводиться.

Значне місце у розгляді концептів гібридизації і транскультуралізму в межах і поза межами постколоніальних студій посідає аналіз філософськіх систем карибських мислителів і карибського типу культури, внаслідок чого може скластися поверхове враження, що ця тема стосується лише певного типу культур карибського басейну періоду модернізації і глобалізму, і що до сучасних пострадянських - вужче - східнослов'янських проблем - це має досить віддалений стосунок. Проте якраз карибська філософія, що 
будується як значний прошарок сучасної компаративістики у галузі взаємодії культур - безпосередньо стосується проблем вибору шляхів подальшого постколоніального розвитку пострадянських культур, зокрема у нашій країні. Визначення останніми роками на державному рівні курсу на мононаціональну культуру, архаїзація і кластеризація, анклавізація вітчизняного буття, попри декларації про необхідність модернізації i вестернізації, невизначеність і неоднозначущість концепту «Європа»у сучасному світі, розвиток ксенофобії, що неминуче виникає при анклавізації, надто затягнений постколоніальний стан транзиту від імперії до модернізації, знову і знову повторення радянського дискурсу і типово радянських ідеологічних замкнених схем, пошук ворогів не тільки за умовними кордонами, але й на таких само умовних прикордоннях і навіть всередині власної території, - все це засвідчує, що проблема взаємодії культур, гібридизації та транскультурації - ще не визнається однією 3 приоритетних напрямків діяльності держави. Тому категорії транскультурації і гібридності, вперше висунуті карибськими теоретиками, не тільки не є для нас абстрактними і малоцікавими, але й, напроти, становлять надзвичайну важливість. Адже постколоніальні війни, які ми переживаємо, виправдовуються ідеологією необхідності анклавної чистоти національної культури, незалежності ії від колишньої панівної культури метрополії, принциповою неможливістю культурної взаємодії. Примордіалізм та есенціалізм у визначеннях етносів, що, зокрема, було прийнятим у радянських дослідженнях, вже давно у сучасній історичній соціології і культурних студіях поступилися місцем модерністичним напрямам думки періоду глобалізму, де карибські за походженням теорії транскультурації і гібридизації давно вже поширилися на весь світ. Закони транскультуралізму і модерної гібридності - глобальні.

Складність в аналогіях полягає в тому, що креолізація для карибської культури означала поєднання різних не стільки етносів, але й рас. Так само в сучасній Європі про анклавізацію і гібридизацію говорять виключно у зв'язку зі взаємодією різних рас: корінних європейців і мігрантів з Азії і Африки. Проблема в тому, що близькі східноєвропейські культури не розрізняються в світі так яскраво, як креоли в Карибському регіоні i мігранти в Європі. Тому подібні дослідження передусім мають цікавити 
саме східнослов'янських учених, де існують і дотепер не вирішені проблеми взаємодій надто близьких, а не зовсім далеких культур, і проблеми гібридних і транскультурних ідентичностей. В нас $\epsilon$ також свої контрапункти тютюну i цукру, користуючись метафоричною назвою знакової для транскультуралізму книжки Ф. Ортіса...

А, 3 іншого боку, теоретики потрадянського транзиту, що належать до різних країн, часто-густо обіймають протилежні позиції в оцінці того рівня гібридності і непрозорості, що відрізняє одну близьку культуру культуру колишньої метрополії - від іншої культури - колишньої підлеглої території. Тому для українських компаративістів першочерговим завданням може вважатися не тільки виокремлення власного культурного досвіду від досвіду колишніх метрополій, але й визначення гібридних транскультурних елементів, котрі складають частину української рухомої ідентичності.

Сучасні українські філософи-гуманітарії, культурологи i літературознавці, вже давно звертають увагу на феномен транскультурації як можливий спосіб подолання роз'єднання внаслідок політичної i економічної кризи і довготривалих військових конфліктів у сучасному українському соціумі.

Так, М. Требін і Т. Чернишова зазначають, що «транскультурація прошиває собою весь простір культури та соціуму епохи глобалізації, проявляючись і в етноконвергенції, і у висуненні принципу гібридності замість колишньої «чистоти», і в зміні ставлення до національних мов, культурних традицій і самого поняття нації-держави, що втрачають свій самодостатній характер, поступаючись місцем процесам транснаціоналізації та поліглосії, пов'язаним 3 критичним космополітизмом. Транскультурація $є$ новим способом соціального й мовного мислення, породжуючи нові стосунки між культурами й мовами, нове розуміння сучасної комунікації» [Trebin 2014: 15-20].

Очевидним стає той факт, - зазначає, наприклад, Т.В. Надута, - що акценти на національній ідентичності, етнічності, расі, які переважали у дослідженнях творчості письменників 3 транснайціональною ідентичністю, виявляються нежиттєздатними у сучасну епоху «планетаризації людства». Широке поле міжрасових та 
міжцивілізаційних взаємодій визначає сьогодні новий тип сучасної художньої свідомості як транскультурної. [Naduta 2012: 133].

Характерним феноменом, - зауважує дослідниця, - стала поява світових транскультурних студій у рамах порівняльного літературознавства (Eugenio Benitez, «Proceedings in Pacific Rim Conference in Transcultural Aesthetics», 1997; Stephen Stankman, «Other others: Levinas, Literature, Transcultural Studies», 2010; David Blake, «Transcultural Japan», 2008). Зважаючи на загальну тенденцію розвитку дискурсу, транскультура, поміж іншим, розуміється як інтермедіальна взаємодія різних видів культурних дискурсів [Надута 2012: 134]. Процеси транскультурації в літературі, на відміну від кроскультурності, проявляються у створенні художнього світу (герой, сюжет, локус, стиль, інтертекстуальні зв'язки тощо) за межами існуючих національних, художніх, естетичних традицій як «вродженої», так і набутої культур. Тому дослідження подібних феноменів стає центральним завданням порівняльного літературознавства $\mathrm{y}$ його планетарновизначеному масштабі [Naduta 2012: 135].

«Сама природа літератури, - справедливо зазначає Н. Висоцька, заперечує будь-які домаганння на «чистоту крові», обумовлює - через постійну циркуляцію, «взаємозапиленнння», відгуки и відлуння одне одного - культурне «мулацтво» будь-якої національної літератури» [Vysotskaya 2011: 30-48]. Авторка говорить про визнання необхідності вийти за межі традиційного підхода до вивчення світової словесності у форматі окремих національних літератур або, як мінімум, необхідності «модифікувати його у відповідності з сьогоднішніми реаліями. Нестримний процес глобалізації у галузях, що безпосередньо не тосуються 3 літературою, передусім в економіці, змушують говорити по застарілість (бодай теорететичну) самого поняття національних держав як продуктивнї наукової концепції» [Vysotskaya 2011: 30-48]. Таким чином, концепт транскультурації пов'язаний з більш узагальненим антиесенціалістським розумінням ідентичності, що є властивим нашому часу, і $є$ спвзвучним цьому розумінню [Vysotskaya 2015: 10]. Транснаціоналізація економічних і культурних єдностей веде по послаблення національної моделі i поступовому відході від мислення виключно у національних категоріях. Це спостерігається в усіх гуманітарних дисциплінах. Мова йде вже не просто 
про інтертектуаьність, а про наднаціональну текстуальність сучасних книжок, що призводить до формування навіть вже не «світової», а «глобальної літератури» - зауважує Н. Висоцька [Vysotskaya 2011: 30-48].

Теорія i практика прикордонного існування людини 3 iii транскультурною ідентичністю - між державами, мовами, культурами досліджувалася передусім літераторами, філософами, критиками латиноамериканського походження у зонах міжкультурних контактів внаслідок взаємовпливів і невідворотних процесів гібридизації.

Дослідники зауважують, що поняття єдиної національної культури відбувається також і у внутрішніх субкультурах : наразі єдина національна культура усвідомлюється як тоталізуюча, пригноблююча, патриархальна, i їй протставляються групові культурні практики субкультурних фрагментованих єдностей, що формується на грунті різних ознак, не тільки расово-національної, регіональної, але й гендерної, сексуальної, дізабілиті тощо. Але групова ідентичність може бути не менш тоталітарною по відношенню до індивіда, ніж загальнонаціональна. Теорія мультикультуралізму, що протиставляла різні групові практики у своїй хоча й плюралістичній рівності, але онтологічній незмінності і у відсутності взаємопроникнення, як сталі незмінні константи, саме в цьому потерпіла поразку, виявилася перевагою лише домінуючої культури.

Гібридність національної культури створює їі нову єдність, цілісність багатьох компонентів на протилежність від роздрібленості культур при мультикультуралізмі. Це не $\epsilon$ повернненням до колишньої єдиної монологічної і моноідеологічної національної культури, навпаки, всіляко підкреслюються риси транснаціональності, транскультурності, гетерогенності, «метисності», гібридності, «меланжу», - без яких не може існувати жодна сучасна європейська культура. Н. Висоцька пропонує образ ризоми для означення багатовимірності засад національної культури за відстності єдиного головного [Vysotskaya 2011: 30-48]. Варто відмітити, що все, означене дослідницею, має стосунок не тільки до літератури США, але й ширше значення для сучасного європейського світу, зокрема, для України.

Окремо постає питання про необхідність збереження культурних відмінностей при транснаціональній взаємодії культур, діалозі культур, що 
має відбуватися у пошуках динамічної рівнодії. Частиною цієї проблеми у постколоніальній літературі стає мова центру, колишньої метрополії, якою користуються письменники периферії, колишньої колонії. Для багатьох письменників периферії, як свідчать дослідники, мова центру, передусім англійська, залишається другою рідною, адже лише на мові центру їх твори мають змогу дійти до світу, а не лише до носіїв рідної мови периферії. Водночас передання локального досвіду мовою центру усвідомлюєтья як небезпека гомогенізації мови і потребує розумного співвідношення локального і глобального.

Як нам видається, ця небезпека дещо перебільшена. Адже мова у у сучасному суспільстві перестає бути домінантним визначальником громадянської політичної нації, i мова центру пеертворюєься на національний варіант мови периферії - не стільки граматично, скільки за цим самим локальним досвідом буття. Лесь Курбас, самотужки відвідавши на початку 1920-х років Московський театр Мейєрхольда, вистави за Н. Ердманом, зауважував, повернувшися, що все це нам не підходить, тому що в нас люди під іншим кутом зору виховані. Тобто йшлося не про мову, а про цей самий локальний досвід, що відрізняє рецепцію українського глядача i не може бути зведений до мови. Наприклад, лінгвісти i письменники вже кажуть про наявність національного варіанту російської мови України, що історично відчуває на собі вплив української мови, і не тотожного мові центру, так само, як існує північноамериканський, канадський, австралійський тощо варіанти британської англійської мови. Врешті-решт повна гомогенізація відбутися не може.

Отже, проблеми глобалізації привертають увагу не тільки філософів, політологів, соціологів та культурологів, але й літературознавців, що зацікавлені суперечливими тенденціями формування транскультурного простору. Особливої уваги заслуговує дослідження динаміки формування транскультурного феномену в сучасній літературі - тієї іï складової, що раніше вивчалась крізь призму етнічного, та аспектів транскультурного, які призводять до створення літературного твору, що за тематикою, проблематикою та поетикою є складним феноменом. Актуальним вважається вивчення всіх форм літературної традиції, національно-етнічної ідентичності. 3 точки зору літературознавства 
дослідження має зосередитись на художньо-естетичних, а не соціальнополітичних аспектах транскультурних процесів.

Існують також в українській гуманітаристиці і критичні погляди на транскультурацію. Так, наприклад, український дослідник культур країн Андійського регіону Ігор Оржицький вважає дискусійним концепт транскультурації і ставить під сумнів демократизм явища транскультурації в країнах Андійського регіону порівнянно 3 «колоніальними» термінами асиміляція i акультурація, адже в них йдеться про загрозу втрати самобутності в результаті міжкультурного контакту. Він наголошує, що взаємодія культур при транскультурації відбувалася мовою домінуючої культури - іспанської чи португальської [Orzhyts'kyy 2016: 26] «Принаймні в Латинській Америці транскультурація відбулась унаслідок вторгнення культури “сильнішоі” на територію культури “слабшоі”, а отже, латиноамериканська культура опинилась у силовому полі іспано- (португало) мовного світу <...> Таким чином Ортіс не взяв до уваги мовний чинник, як це зробив його співвітчизник X. Марінельйо. Тому, за всієї "нейтральності" терміна транскультурація, його конкретно-історичне наповнення об'єктивно означає домінуванняодної 3 культурних складових та, як випливає 3 висловлювання Х. Марінельйо, призводить до усвідомлення нецілісності культури принаймні деякими ії носіями», - зазначає дослідник. [відбувалася мовою домінуючої культури - іспанської чи португальської [Orzhyts'kyy 2016: 26-27]. Натомість I. Оржицький пропонує звернутися до іншого боку транскультурації, що ціннісно не менш важливий, хоч і менш поширений, до концепту інверсії транскультурації, відомому у світовій практиці, під яким розуміється перехід представників престижнішої, розвинутішої або панівної культури на позиції культури “малоі”' (або притлумленої) та - що стосується художньої інтелігенції - творення, принаймні деякий час, в орбіті iii духовно-естетичного та мовного впливу. Інверсія транскультурації, - вважає дослідник, - має широкий світовий контекст і відбувалася в різних культурно-географічних регіонах. Інверсія транскультурації використовуєиться для визначення напрямку транскультураціi, в процесі якого представники більш розвиненою, престижної або панівної культури переходять на позиції культури "малої" (або пригніченої), асоціюючи себе з даною культурою і створюючи твори в 
орбіті їі духовно-естетичного або мовного впливу. Це явище спостерігається у різних культурно-географічних регіонах [Orzhyts'kyy 1998].

Хоча теоретик феномену акультурації М. Гершковіц вважав, що у процесі взаємодії культур зміни відбуваються в моделях обох культурних спільнот, - зазначає I. Оржицький, - але латиноамериканські культурологи цей термін сприймають негативно, так «програмний текст знакового перуанського письменника та антрополога Х. М. Аргедаса називається «Я не акультурований!» [Orzhyts'kyy 2016].

3 латиноамериканських теорій терміни культурна гетерогенність, акультурація, гібридність, транскультурація увійшли до культурології США. Щодо Європи, то сьогодні визнається, що латиноамериканський досвід був ще допостмодерністським і незалежним від останнього, випереджаючи його.

«Так дискурсивна гетерогенність збігається (передуючи йому) 3 поняттям гібридності, що його вже на початку 80-х рp. Г. Бгабга запровадив у постколоніальну теорію, давши стимул Ц. Тодорову ужити в 1986 р. Термін - гібридна культура, до якого наприкінці того десятиліття удасться й аргентинський дослідник Нестор Гарсія Канкліні» [Orzhyts'kyy 2016: 18]. Утім, самі ж латиноамериканісти зазначають, що, очевидно, першим, хто вжив термін гібридний у гуманітарних науках, був М. Бахтін, хоча він уживав його в контексті суто літературознавчому, говорячи про змішання зумисне і саме стилів та мов, а не про спонтанну взаємодію різних культурних елементів» [Orzhyts'kyy 2016: 18-19].

Засади транскультурності закладено вже в основних документах Європейської спільноти. Але принципи мультикультуралізму, що ще кілька десятиліть тому вважалися відкриттям, сьогодні не спрацьовують. Існуючі категорії мультикультуралізму як взаємоіснування багатьох культур в одному суспільстві і інтеркультуралізму як взаємодії між цими культурами - сучасними дослідниками визначаються як застарілі. Їм на зміну приходить концепт транскультуралізму, що надає можливості вийти за межі своєї культури і перейти до іншої культурної спільноти, розширюючи контексти культури. Нові цифрові комунікативні технології і міжнародні мережеві транскомунікативні спільноти ставлять під сумнів існування національних культур і національних держав і змушують переосмилити 
концепти мультикультуралізму як кульурного різноманіття у співіснуванні етнічних культур. Саме за транскультуралізмом, як вважає багато дослідників культури, залишається майбутнє.

«Розпад колоніальних імперій (першою 3 яких була британська, а останньою - радянська) узаконив культурний плюралізм, що веде до множинної ідентичності та / або до безлічі культур, носієм яких може одночасно бути окремий індивід, - зазначає К Разлогов. - Тим часом мультикультуралізм як і раніше грунтувався на окремому лідерство в кожному цивілізованому суспільстві. Інтеркультуралізм ввів в обіг концепцію діалогу між спільнотами (і їх лідерами). Наступний крок - це визнання транскультуралізма як парадигми нової концепції лідерства» [Razlogov 2012: 5-7].

3 кінця 1990-х років у світовій філософії і культурології, як і у літературознавстві, відбувається критичне осмислення категорій західної модерності у термінах глобалізації і відповідно критика концептів національних держав і національних літератур, а також концепту світової літератури, котрі переходять до постнаціональної літератури, що призводить до зміни художніх парадигм. I це відображається у принципах взаємодії світової літератури і національних літературних традицій, всесвітності і локальності в моделюванні національної пам'яті. У новому розумінні світової літератури головним стає не стільки пошук подібностей, як у глобальному проекті, скільки пошук розбіжностей, усвідоменні Іншого як незнаного. Змінюється і само поняття світової літератури, привертається все більша увага до міжкультурної взаємодії. Світову літературу пропонується розглядати не у межах національних традицій, а згідно з певними культурними матрицями глобального світу, як то історична травма, втрата ідентичності тощо. 3 одного боку, це надає голос маргінальним особистостям, що знаходяться між культурами: імігрантам, мультикультурним письменникам, - a, з другого боку, це позначається на самій структурі літературної творчості, яка стає багатостильовою [Tlostanova 2004].

Нова транскультурна естетика епохи глобалізації змінює як моделі національних літератур, так i саму ідеологію глобалізму 3 iii неолібералізмом і націоналістичними дискурсами, і існує у межах 
прикордонного мислення, моделей прикордоння культур, надаючи право голоса i створення власних дискурсів Іншому. Естетика прикордоння і породжує таке культурне явище, як транскультурація, що в галузі гуманітаристики осмислюється як взаємодія культур без їх змішання в єдине ціле.

Мультикультуралізм і транскультуація репрезентують своєрідну дихотомію, оппозицію, два головних протилежних історично змінних концепта сучасної постколоніальної теорії, як і епістемологічних студій сучасної культурної і соціологічної антропології. Транскультурація до певної міри $є$ альтернативою мультикультуралізму як продукту глобалізму. Транскультурація як основний тренд деколоніалізму принципово антиглобалістична і має відмінну від мультикультуралізму риторику Іншого.

Термін «транскультурація» у сучасних постколоніальних теоріях і у філософській антропології вживається принаймні у двох значеннях - як сучасна модель глобалізації і як принцип побудови діалогу культур. Транскультурація у першому розумінні простистоїть концепту монокультурної нації-держави, - як вважає М.Тлостанова, «конструкту вельми умовного, історично і географічно обмеженого і наразі приреченого» [Tlostanova 2004: 48-57]. У сучасному глобальному світі міфічна модель чистої, негібридної культурної ідентичності виявляється неможливою, ані в минулому, ані в теперішньому. Ще Фернандо Ортіс у книзі «Кубинський контрапункт тютюну і цукру» 3'ясував на прикладі Куби, що нація-держава $\epsilon$ не монокультурною, а транскультурною. Ті ж процеси спостерігаються у сучасному Андському регіоні Латинскої Америки, де розвиваються інтеркультуралізм у багатонаціональних державах.

Уругвайський літературознавець Анхель Рама переніс термін Ортіса у літературні дослідження, і цей підхід до аналізу знакових текстів літератури континенту, запропонований у його книзі «Транскультурація в латиноамериканській прозі» (1980).

Транскультурація у взаємодії культур розглядається не як присвоєння культури Іншого, а як паритетний діалог культур без повного синтезу, злиття, із залишком певної непрозорості культури Іншого, що запобігає присвоєнню. Характеристики сучасності пов'язані саме 3 процесами гібридизації і транскультурації. 
М. Тлостанова бачить генезу транскультурації як діалогу культур у теорії діалогу Бахтіна и Лотмана. Діалогічна модель Лотмана передбачила головну проблему транскультурації - орієнталістську спрямованість європейської культури, яка не тільки оцінювала Іншого зі своєї центральноєвропейської точки зору, але й потребувала Іншого і як реципієнта, і як дзеркала, дивлячись в яке, можна побачити змінений образ себе самого. Теорію діалогу було відроджено у постколоніальних дослідженнях у 1980ті роки. Для семіотичної теорії Лотмана суттєвим було поняття кордону, точки максимальної напруги діалогу культур, де чужий текст засвоюється шляхом трансформації, народження нових смислів, втім, залишаючи можливість неповного перекладу, наявнсті певних темних місць Іншого, що створюють різницю і залишають Іншого цікавим як неповністю Свого. [Lotman 2002: 273; Lotman 2000: 262]. Це основний принцип транскультурації, котра отримала популярність пізніше у постколоніальних студіях. Семіотична теорія культури Ю. Лотмана призводила до ідеї не монокультури, а полікультури, що зацікавлена у багатьох кодах для самозбереження i відтворення. Культура як комунікативний механізм репрезентує себе у мові (мовах) культури, що не може не бути діалогічною у сучасному транскультурному світі.

Якщо акультурація засвоює нову культуру в односпрямованому процесі, то, за Ортісом, транскультурація має дві фази: декультурацію (втрату) и створення нової культури (неокультурацію). Ці дві фази однаково важливі: як руйнування культур, так і створення нових. Ортіс продемонстрував на прикладі взаємоспрямованої культурної взаємодії у кубінському суспільстві, що культурна однорідність не може існувати навіть тоді, коли наявні історично домінуюча і підлегла культури, тому що сама дімінуюча культура відчуває на собі вплив культури, яку вона пригноблює. Стан домінуючої культури не є раз і назавжди визначеним, він змінюється історично. Характер взаємодії між домінуючою i пригнобленою культурами не $є$ конфліктним тому, що внаслідок такої взаємодії створюються нові культурні коди, як це відбулося на Кубі. Тобто діалог двох культур породжує не знищення, а народження нового, третього типу культури, якого не було дотепер. Якщо мультикультуралізм походить від західного розуміння центру i 
периферії, то транскультуралізм реабілітує поняття периферії, централізуючи рухомі ідентичності периферії і зміщуючи самий концепт центру. Ортіс вносить в розуміння кордонів колоніального світу рухомість, доводить змінність цих кордонів, розуміючи транскультурацію як процес постійних змін на кордонах культур.

У 1990-х роках теорію Ортіса було критично переосмислено у термінах глобалізаційних студій як модель прикордонного культурного мислення. М'яка уніфікація глобального світу, на відміну від жорсткого колонізаційного світу, обов'язково включала в себе категорію різноманітності, що для урівноваження поєднувалася 3 тенденціями транскультурації на кордонах. Водночас для транскультурації важливим $є$ не етнокультурне різноманіття, а гносеологічне. Сучасна теорія транскультурації додає до старого порівняльного дискурсу культурної багатоманітності - новий транснаціональний дискурс доби цифрових технологій.

Транскультурація як епістемологічна модель державотворення $\epsilon$ особливо актуальною для сучасної України з іiї дотепер не визначеним культурним кодом прикордонних культур як сходу, так і заходу. Але вже очевидно, що запропонована монокультурна модель в умовах глобального цифрового світу вже не спрацьовує і може бути визначеною як архаїчна. Взаємозв'язок прикордонного, або Іншого мислення висвітлюється у сучасних альтернативних теоріях, наближених до транскультурації, як і проблеми подвійного перекладу. I хоча дослідники пишуть про взаємини світу західного i незахідного у період постколоніальної свідомості, але основні принципи транскультураціції можуть бути застосованими i до пострадянського світу як постколоніального і постімперського. Концепт культурного перекладу сьогодні усвідомлюється не стільки у лінгвістичному аспекті, скільки в аспекті постколоніальної дійсності як акт міжкультурної комунікації в добу модерності, що розуміється також і як нова колоніальність.

Модерність, як і глобалізм, нав'язує свою систему цінностей усьому іншому світу, керуючись принципами односпрямованих процесів транскультурації і перекладу, тому модерність довгий час залишалася у рамках імперськи-колоніального світобачення, а будь-який переклад нормувався західною культурою як еталонний лише 3 позиції заходу. 
Сьогодні ця односпрямованість продовжується у філософії неолібералізму як глобальне навернення усього світу до ринкової економіки і ідеології споживання, не залишаючи місця для альтернативних поглядів.

Принцип подвійного перекладу у межах дихотомії трансляція/транскультурація було сформульовано В. Міньоло [Mignolo 2002: 927-954;934] і Ф. Чиуї. Це не просто переклад 3 мови однієї культури на іншу, а взаємоспрямований процес діалогу і взаємодії імперських та колоніальних мов, що більш не асоціюються з нацією і не дорівнюють нації, адже процес транскультурації руйнує дихотомію Нації і Іншого. Старий жорсткий зв'язок між нацією, мовою та письмом порушується. Транскультурація описується як прикордонний конфлікт між мовами панівної і пригніченої культури в умовах деколонізації. Подвійний переклад і розуміння нового гносеологічного значення кордону культур як перехрестя і взаємодії культур переосмислює модель панування єдиної західної культури [Tlostanova 2010: 48-57].

Теорія транскультурації карибських дослідників регіону Е. Гліссана, У. Харріса та ін. дещо збігається з теоріями постмодернізму Ж. Дерріди, Ж.Дельоза, Ф. Гватаррі, М.Фуко, існуючи незалежно від останніх.

Отже, транскультурація висуває принцип гібридності замість архаїчного принципу чистоти національної культури, декларує зміну ставлення до національних мов, культурних традицій і самого поняття нації-держави, що поступаються місцем процесам транснаціоналізації і поліглосії, пов'язаним 3 принципом космополітизму. Це нові стосунки між мовами і культурами. У кінцевому рахунку це нові імагологічні взаємодії між Своїм та Іншим, це пошук нової єдності різних Інших.

\section{REFERENCES:}

1.Vyisotskaya, N. A. (2011). Transkultura ili kultura v transe? In: I. SHaytanov (Ed.), Problemyi sovremennoy komparativistiki (pp. 30-48). Moskva, Rossiya: Jurnal «Voprosyi literaturyi». http://voplit.ru/eTextbook/2011/2011-3/2011-3/2011-3.html\#32 (In Russ.). 2.Vyisotskaya N. A. (2015). Protsessyi kulturnoy gibridizatsii i transkulturatsii kak faktoryi smyisloporojdeniya amerikanskogo «teksta». In : T. V. Voronchenko (Ed.), Rossiya - Zapad - Vostok: vzaimodeystvie kultur i literatur : mejdunar. nauch. konf. (pp. 8-13). CHita, Rossiya: Zabaykal. gos. un-t. https://b-ok.org/book/3105869/0050cd (In Russ.). 
3.Lotman, YU. M. (2002). Istoriya i tipologiya russkoy kulturyi. (p. 273). Sankt-Peteburg, Rossiya: Iskusstvo SPB https:// imwerden.de/pdf/lotman_istoriya_i_tipologiya_rus_cultury.pdf . (In Russ.).

4.Lotman, YU. M. (2010). Semiosfera. (p. 262). Sankt-Peteburg, Rossiya: Iskusstvo-SPB. http://yanko.lib.ru/books/cultur/lotman_semiosphera.htm . (In Russ.).

5.Naduta, T. V. (2012). Transkul'turna model' suchasnoyi sino-amerykans'koyi literatury : Teoretychnyy aspekt. Visnyk Dnipropetrovs'koho universytetu imeni Al'freda Nobelya. Seriya Filolohichni nauky, 1 (3), 133-139. http://phil.duan.edu.ua/images/PDF/2012/1/19.pdf (In Ukr.).

6.Orzhyts'kyy, I. O. (2016). Etno-natsional'na y kul'turna svoyeridnist' literaturnoho protsesu v krayinakh Andiys'koho rehionu (Peru, Boliviya, Ekvador) u 20-kh - 80-kh rokakh KhKh $\quad$ stolittya. Kharkiv, Ukrayina: 2016. http://shron1.chtyvo.org.ua/Orzhytskyi_Ihor/Etnonatsionalna_i_kulturna_svoieridnist_literaturnoho_protsesu_v_krainakh_Andiiskoho_rehi onu_Peru_B.pdf (In Ukr.).

7.Orjitskiy, I. A. Transkulturatsii inversiya (1998). In : S. YA. Levit (Ed.), Kulturologiya. XX vek. Entsiklopediya $v$ dvuh tomah. Sankt-Peterburg, Rossiya : Universitetskaya kniga. http://terme.ru/termin/transkulturacii-inversija.html http://psylib.org.ua/books/levit01/txt111.htm\#21 (In Russ.).

8.Razlogov, K. Transkulturalizm v deystvii. (2012). In : E. S. SHteyner (Ed.), Orientalizm / oksidentalizm: yazyiki kultur i yazyiki ih opisaniya. Orientalism / Occidentalism: Languages of Culture vs. Languages of Description : Collected Papers. Ros. in-t kulturologii (pp. 5-7). Moskva, Rossiya : Sovpadenie. https://www.hse.ru/data/2013/02/15/1308253228/Steiner\%2520Orientalism\%2520Book\% 2520Full.pdf (In Russ.).

9.Tlostanova, M. V. (2004). Postsovetskaya literatura i estetika transkulturatsii. Jit nikogda, pisat niotkuda. Moskva, Rossiya : URSS. https://utka.su/k69mU (In Russ.).

10.Tlostanova, M. V. (2010). Transkulturatsiya kak sotsialno-kommunikativnaya model epohi globalizatsii. Vestnik Novosibirskogo gosudarstvennogo universiteta. Seriya: Filosofiya. Novosibirsk, Rossiya : NGU. 8(3), 48-57. https://nsu.ru/xmlui/bitstream/handle/nsu/4652/07.pdf?sequence=1\&isAllowed=y (In Russ.).

11.Trebin, M. P., Chernyshova, T. O. (2014). Transkul'turatsiya yak shlyakh do yednosti suchasnoho suspil'stva. (pp. 15-20). Metodolohiya, teoriya ta praktyka sotsiolohichnoho analizu suchasnoho suspil'stva. Zbirnyk naukovykh prats'. Kharkiv, Ukrayina: Kharkivs'kyy natsional'nyy universytet imeni V. N. Karazina. 20. http://deviantology.spb.ru/etc/Metodologiya_teoriya_i_praktika_sotsiologicheskogo_anali za.pdf (In Ukr.). 
Компаративні досліАження слов'янських мов і Аітератур. 2019. Випуск 35

12.Epshteyn M. (2004). Znak probela. O buduschem gumanitarnyih nauk. (622-634). Moskva, Rossiya : Izd-vo Novoe literaturnoe obozrenie.

13.Bhabha, H.K. (1994). The Location of Culture. London, England: Routledge.

14.Glissant, E. (1997). Poetics of Relation (Betsy Wing trans.). USA: Ann Arbor, The University of Michigan Press. (Édouard Glissant: Originally published in French by Gallimard, 1990)

15.Hutcheon, L. (2002). Rethinking Literary History: A Dialogue on Theory. USA: Oxford University Press.

16.Mignolo, W. 2002. The Enduring Enchantment (or the Epistemic Privilege of Modernity and Where to Go from Here). The South Atlantic. 101 (4). 927-954. p. 934. 17.Ortiz, F. (1995). Cuban Counterpoint: Tobacco and Sugar. Durham and London : Duke University Press.

18.Said, E.W. (1994). Culture and Imperialism. New York, USA: Alfred A. Knopf.

Сильвестжак М. маг., університет м.Бялисток (Республіка Польща)

Sylwestrzak $M$. Magister, University of Biatystok (Republic of Poland)

\section{ТВОРЧІСТЬ ВЛАДИСЛАВА ШЛЕНГЕЛЯ У КОНТЕКСТІ НЕПРОФЕСІЙНИХ ПОЕТІВ ВАРШАВСЬКОГО ГЕТТО}

\section{WLADYSŁAW SZLENGEL'S POETRY IN CONTEXT OF WORKS OF THE GHETTO UNPROFESSIONAL POETS}

У статті аналізується творчість Владислава Шленгеля $і$ непрофесійних поетів варшавського гетто. Непрофесійними поетами вважаються автори, які написали один або кілька віршів присвячених Голокосту. У иентрі уваги автора статті знаходиться поетика творів Шленгеля $і$ інших польсько-єврейських поетів. $У$ статті йдеться також про найважливіші мотиви літератури варшавського гетто, таких як стіна, вікно на арійську сторону, смерть, дитина і ін.

Ключові слова: Владислав Шленгель, поезія, Голокост, варшавське гетто (19401943), польська література. 